\title{
Tutkintoja ja itsensä sivistämistä - kertomuksia aikuislukiosta
}

\author{
PÄIVISIIVONEN
}

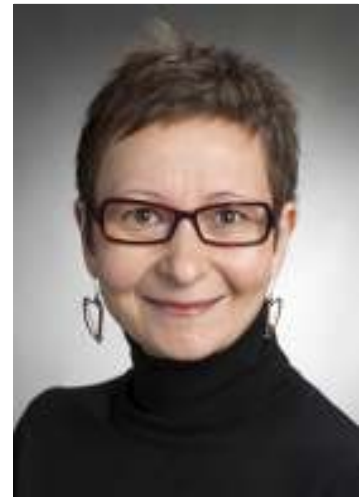

\begin{abstract}
Aikuislukio on "toinen mahdollisuus" yleissivistävään peruskoulutukseen. Se on tarkoitettu erityisesti niille aikuisille, joilla syystä tai toisesta jäi lukio käymättä nuoruusiässä. Yksilöllisen uuden mahdollisuuden tarjoajana aikuislukio on siten merkittävä koulutuksellinen tasa-arvoistaja. Useimmat hakeutuvat aikuislukioon parantaakseen jatko-opintomahdollisuuksiaan ja työuraansa sekä tähdäten sosiaaliseen nousuun. Harvemmille lukio on itsensä kehittämisen ja yleissivistämisen väylä ilman elämässä etenemistavoitteita.
\end{abstract}

Aikuislukiokoulutuksella on Suomessa pitkät perinteet. Yrjö Jahnsson perusti puolisonsa Hilma Jahnssonin tukemana ensimmäisen iltaoppikoulun Suomeen vuonna 1927 tarjoamaan opiskelumahdollisuuksia muun muassa ensimmäisen maailmansodan takia opintonsa keskeyttäneille (Zetterberg 1982, 257; ks. myös Salomaa 2002, 8). Yrjö Jahnsson näki erityisen tärkeäksi opiskelumahdollisuuksien luomisen työssäkäyville aikuisille, jotka halusivat sivistää itseään oppikoulussa: "jotka päivisin ovat töissä, mutta joilla on halua ja tarmoa sen ohella jatkaa opinnoitaan" (Zetterberg 1982, 265). Yrjö Jahnssonin sosiaaliset perustelut iltaoppikoulun perustamiseksi tulivat erityisen hyvin esiin hänen todetessaan, että usein "opinhalu herää ihmisessä vasta varttuneemmassa nuoruusiässä ja usein ovat taloudelliset seikat estämässä varhemmin opintielle antautumista" (mt., 266). Yli 80 vuotta myöhemmin määritellään opetusministeriön teettämässä selvityksessä aikuisten yleissivistävän opetuksen koulutuspoliittisen erityistehtävän olevan edelleen "toisen mahdollisuuden tarjoaminen niille aikuisille, joilla ei ole ollut lapsina tai nuorina mahdollisuutta, kiinnostusta tai kypsyyttä hankkia tätä koulutusta" (OPM 2006, 20).

Suomessa toimii tällä hetkellä noin 50 aikuislukiokoulutusta tarjoavaa oppilaitosta eri puolilla maata ja aikuislukio-opiskelijoita on yli 20000 (IKLO n.d.). Tähän lukuun sisältyvät myös aineopiskelijat, joiden osuus aikuislukio-opiskelijoista on merkittävästi kasvanut 2000-luvulla (ks. esim. Jääskeläinen, Opinsauna 27.10.2007). Paitsi lukion päättötodistukseen ja/tai ylioppilastutkintoon tähtääviä opintoja, voi aikuislukiossa suorittaa kursseja myös yksittäisissä aineissa kuten kielissä tai tietotekniikassa sekä parantaa aiempia arvosanoja. Yksittäiset aikuislukiot tarjoavat myös esimerkiksi peruskouluopintoja tai maahanmuuttajille tai ammattitutkinnon suorittajille suunnattua opetusta. (ks. IKLO 2007.)

Taulukossa 1 on esitetty lukion koko oppimäärää suorittavien aikuisten lukiokoulutuksen opiskelijoiden oppilasmäärät sekä aikuisten lukiokoulutuksessa suoritettujen tutkintojen osuudet prosentteina kaikista lukiotutkinnoista vuosina 2003 ja 2008 (Tilastokeskus 2003, 2008). Koko oppimäärää suorittavien aikuisten lukiokoulutuksen opiskelijoiden opiskelijamäärä on vähentynyt yli 2600 opiskelijalla ja aikuislukioissa suoritettujen tutkintojen osuus kaikista tutkinnoista on alentunut kahdeksasta kuuteen prosenttiin. Myös naisopiskelijoiden osuus on hieman laskenut. Aikuisten lukiokoulutuksen opiskelijoiden suhteellinen osuus on kuitenkin pysytellyt noin 10 prosentissa (Kumpulainen 2009, 26). Vanhempien ikäluok- 
kien suhteellinen osuus koko opiskelijamäärästä on hieman kasvanut vuodesta 2003 vuoteen 2007 (mt., 26-28).

Taulukko 1. Aikuisten lukiokoulutuksen koko oppimäärää suorittavat opiskelijat yhteensä ja naisten osuudet prosentteina sekä aikuisten lukiokoulutuksessa suoritettujen tutkintojen osuudet prosentteina kaikista lukiotutkinnoista vuosina 2003 ja 2008.

\begin{tabular}{|l|r|r|}
\hline & 2003 & 2008 \\
\hline Opiskelijoita & 12892 & 10230 \\
Naisia (\%) & 63 & 57 \\
Tutkintoja (\%) & 8 & 6 \\
\hline
\end{tabular}

Lähde: Tilastokeskus

Yli 80-vuotisesta historiastaan huolimatta aikuislukioiden toiminta on edelleen varsin tuntematonta muille kuin niissä työskenteleville tai opiskeleville. Myös aikuislukion kontekstiin sijoittuva tutkimus on toistaiseksi ollut vähäistä (ks. Jokinen 2002, Kallioniemi 2000, Siivonen 2010). Aikuislukio on kuitenkin toiminut koko olemassaolonsa aikana edelläkävijänä joustavien ja yksilöllisten aikuisten opiskelumahdollisuuksien kuten luokattomuuden ja kurssimuotoisen opiskelun sekä etäja verkko-opetuksen luomisessa ja kehittämisessä (ks. OPM2006, 20; myös Zetterberg 1982, 257-267).

Instituutiona 2000-luvun aikuislukio asettuu kiinnostavalla tavalla yleissivistävän aikuisten koulujärjestelmäkoulutuksen ja elinikäisen oppimisen leikkauskohtaan. Osin ristiriitaisista painotuksistaan ja tavoitteistaan huolimatta itsensä sivistäminen, elinikäinen oppiminen ja tutkintotavoitteinen opiskelu rakentuvat osaksi aikuislukion paikallista toimintakulttuuria (Siivonen 2010, 32-33). Tämä tulee esiin myös artikkelin pohjana olevassa väitöskirjatutkimuksessani aikuislukiosta valmistuneiden opiskelijoiden työstäessä lukion suorittamista aikuisuudessa eikä normatiivisesti nuorena (Siivonen 2010).

Tutkimuksessani tarkastelin koulutettavan subjektin rakentumista elinikäisen oppimisen näkökulmasta 20 aikuislukiosta valmistuneen opiskelijan pääasiassa haastatteluin tuotetuissa narratiivisissa elämänhistorioissa. Työni lähtökohtana oli koulutettavuuden tulkintoihin sisältyvä ristiriita elinikäiseen oppimiseen sisältyvän kaikkia koskevan koulutettavuuden ja koulujen ylläpitämän yksilön luonnollisiin kykyihin perustuvan koulutettavuuden välillä (ks. Räty \& Snellman 1998). Tutkimuk- seen osallistuneista kaksitoista oli alle 40-vuotiaita, neljä 40-60-vuotiaita ja neljä yli 60-vuotiaita Vanhin tutkimukseen osallistunut oli 66 vuotta. Tutkimukseen osallistuneista viisi oli miehiä ja 15 naisia. Tässä artikkelissa esitetyt Henrin (34 v.) ja Ainon (40 v. $)^{1}$ esimerkkitarinat tekevät näkyväksi koulutettavuuden suhteen rakentuvia sosiaalisia eroja suhteessa ikään, sosiaaliluokkaan ja sukupuoleen. Ne myös valottavat suoritussuuntautuneen ja joustavan oppimisen mallin mukaisia tapoja rakentaa elämänhistoriallista jatkuvuutta.

\section{Yleissivistyksen kartuttamista ja elin- ikäistä oppimista työelämän ehdoilla}

Yhdessä vapaan sivistystyön oppilaitosten kanssa aikuislukiot erottuvat ammatillista aikuiskoulutusta tarjoavista oppilaitoksista tarjotessaan aikuisille mahdollisuuden kartuttaa yleissivistystään. Aikuislukion ensimmäisenä tehtävänä määritellään aikuisten perusopetuksen ja lukiokoulutuksen opetussuunnitelman perusteissa (OPH 2004) "antaa opiskelijalle mahdollisuus täydentää laaja-alaisesti yleissivistystään”. Itsensä kehittämistä ei kuitenkaan nähdä aikuisten perusopetuksen ja lukiokoulutuksen opetussuunnitelman perusteissa itseisarvona sinänsä, vaan opiskelu, työ ja hyvinvointi nähdään sidoksissa toisiinsa. Lukiossa hankitun yleissivistyksen ajatellaan sekä parantavan jatko-opiskelumahdollisuuksia että ammatillisia valmiuksia ja työelämässä menestymisen yleisiä edellytyksiä. "Tavoitteena on, että opinnot auttavat opiskelijaa kohtaamaan entistä luovemmin ja joustavammin muuttuvan maailman haasteet." (OPH 2004.) Myös Turun iltalukion rehtori ja Iltakoulujen liiton puheenjohtaja Erja Vihervaara erottaa (HS 20.2.2007) aikuislukioiden suoritustavoitteisen aineopiskelun ja työväen- ja kansalaisopistojen harrastemaisemman toiminnan, vaikka näkeekin edelleen aikuislukion yhtenä tärkeänä tavoitteena myös yleissivistyksen kartuttamisen.

Yleissivistyksen merkitys korostuu jatkuvasti muuttuvassa työelämässä, jossa tarvitaan monitaitoisia yksilöitä (Filander 2007, 269). Tämä on otettu joustavasti huomioon aikuislukioiden kurssitarjonnassa luomalla mahdollisuuksia osaamisen päivittämiseen ja täydentämiseen (OPM 2006, 20). Aikuislukiot ovat vastanneet työelämän odotuksiin ja omaksuneet elinikäisen oppimisen periaatteet paitsi jatkuvasta oppimisesta ja itsensä kehittämisestä myös oppimisen kiinnittymisestä talouselämän motiiveihin (Siivonen 2010). Tämä ei ole 
yllättävää elinikäisen oppimisen painottaessa erityisesti aikuiskoulutuksen merkitystä riittävän työvoiman takaamiseksi yhteiskunnassa (ks. esim. OPM2006, 25).

Kaiken kaikkiaan elinikäinen oppiminen on omaksuttu hämmästyttävällä poliittisella yksimielisyydellä kehittyneissä länsimaissa 1900- ja 2000luvun vaihteessa (Alheit \& Dausien 2002) - mukaan lukien Suomi, jossa on perinteisesti arvostettu koulutusta. Elinikäinen oppiminen onkin houkutteleva luvatessaan tasa-arvoisia oppimismahdollisuuksia kaikille huolimatta iästä, sosiaaliluokasta tai sukupuolesta. Kaikilla on kyky oppia läpi elämänsä. Elämänlaajuinen oppiminen puolestaan korostaa oppimisen ja itsensä kehittämisen merkitystä kaikissa oppimisympäristöissä ja nonformaali, työpaikoilla, kansan- ja työväenopistoissa tai kansalaisjärjestöissä tapahtuva, ja informaali arkielämän oppiminen on julistettu ensisijaisiksi oppimisen muodoiksi (Tushling \& Engemann 2006, 455). Elinikäinen ja elämänlaajuinen oppiminen on tarjonnut tervetulleen vaihtoehdon erityisesti niille aikuisille, joilla ei ole ollut erilaisista syistä johtuen mahdollisuutta oppia, kouluttautua ja sivistää itseään.

Aikamme koulutuspoliittisena linjauksena ja suurena koulutuskertomuksena elinikäinen oppiminen kääntyy kuitenkin vaateeksi yksilön "oikeasta asenteesta" ja "halusta oppia". Ne, jotka eivät opi ja kouluttaudu ovat vaarassa syrjäytyä ja muodostavat riskin yhteiskunnan kilpailukyvylle ja hyvinvoinnille (ks. esim. Brine 2006; Fejes 2005, 2006). Yksilöltä tämä edellyttää jatkuvaa liikkeellä oloa, joustavuutta, sopeutumista sekä vastuuta omasta työllistettävyydestään (esim. Brine 2006). Elinikäinen oppija on aktiivinen, vastuullinen, määrätietoinen, itsenäinen ja itseohjautuva yksilöllinen oppimisen kuluttaja, joka käyttää joustavasti hyödykseen ympärillään olevia oppimismahdollisuuksia; hän on aktiivinen subjekti, joka tunnistaa jatkuvan oppimisen tarpeensa sekä oppimisprosessin loputtomuuden (Edwards 2002, 359; ks. myös Edwards 1997). Hän on itse vastuussa paitsi omasta oppimisestaan myös selviytymisestään uhkien ja jatkuvan muutoksen sävyttämässä riskiyhteiskunnassa (ks. esim. Jauhiainen \& AlhoMalmelin 2004).

Nyyssölä ja Hämäläinen $(2002,42)$ ovat kiteyttäneet elinikäisen oppimisen perusajatuksen seuraavasti: 'Ihminen kykenee oppimaan koko ikänsä ja selviytyäkseen hänen on opittava koko ikänsä.” Tähän kiteytykseen sisältyy paitsi mahdolli- suus myös vaatimus elinikäisen oppimisen välttämättömyydestä, jota perustellaan yhteiskunnassa vallitsevalla jatkuvalla ja pysyvällä muutoksella ja epävarmuudella, josta selviäminen edellyttää yksilöltä jatkuvaa ja elämänlaajuista - formaalia, nonformaalia ja informaalia - oppimista ja opiskelua ja joksikin tulemista.

Tässä artikkelissa kuvaan tiivistetysti, miten väitöskirjatutkimukseeni (Siivonen 2010) osallistuneet aikuislukiosta valmistuneet opiskelijat rakentavat elämänhistoriallista jatkuvuutta, koherenssia (Linde 1993) suhteessa omaan kykyynsä opiskella ja oppia selittäessään koulutustiensä katkosta. Millaisilla koherenssimalleilla he rakentavat siltaa tuon katkoksen yli? Millainen kompetentti koulutettava subjekti selonteoista piirtyy esiin? Ja miten koulutettavuuteen liittyviä sosiaalisia eroja suhteessa ikään, sosiaaliluokkaan ja sukupuoleen rakennetaan? Lisäksi tarkastelen haastaako ja millä tavoin muodollisen koulutuksen ulkopuolella tapahtuva nonformaali ja informaali oppiminen formaalin koulutuksen merkitystä.

\section{Metodologisia näkökulmia}

Lukiessani koherenssin, jatkuvuuden, rakentumista yksittäisissä elämänhistorioissa (Linde 1993) tarkastelen, miten aikuislukiosta valmistuneet opiskelijat rakentavat jatkuvuutta suhteessa omaan kykyynsä opiskella ja oppia selittäessään lukiokoulutukseen osallistumistaan aikuisuudessa, eikä normatiivisesti nuoruudessa. Vastoin elinikäisen oppimisen periaatteita, joiden mukaisesti kaikkia rohkaistaan opiskelemaan kehdosta hautaan, lukio-opiskelu aikuisuudessa luo elämänhistoriallista epäjatkuvuutta, jota Linden $(1993,152)$ mukaan täytyy arvioida ja selittää. Elämänhistoriallinen kerronta toimii tällöin positiivisena resurssina ja mahdollisuutena kertojalle rakentaa itsestään kompetentti opiskelija ja oppija (mt., 124).

Keskusteluun osallistujilla on käytössään erilaisia kulttuurissa hyväksyttyjä tapoja luoda jatkuvuutta. Minän kertominen pätevänä ja ajassa jatkuvana ja riittävän perustelun antaminen tietylle tapahtumalle (Linde 1993), esimerkiksi lukion suorittamiselle aikuisuudessa eikä normatiivisesti nuorena, ovat tärkeimpiä kertojan käytössä olevia kerronnallisia resursseja. Elämänhistoriallisessa kerronnassa kertoja ja päähenkilö ovat erillisiä, mikä mahdollistaa sen, että kertoja voi kommentoida ja arvioida päähenkilön toimintaa ja silti aina 
itse osoittautua päteväksi (Linde 1993, 123-124). Myös yhteiset kulttuuriset kertomukset, kuten koulutuskertomukset, toimivat kerronnassa jatkuvuuden rakentamisen resursseina (Komulainen 1998, 34-38). Koulutuskertomuksissa koulutus liittyy sellaisiin käsitteisiin kuin "uusiutuminen", "kehitys" ja "edistys" (Popkewitz 1991, 34-35). Tulkitsen myös elinikäisen oppimisen koulutuskertomuksena "poliittisen ajattelun järjestelmänä”, joka ei kuitenkaan ole sisäisesti yhtenäinen, vaan johon sisältyy myös ristiriitoja (Billig ym. 1988).

Aikuislukio sijoittuu elinikäisen oppimisen ja koulujen ylläpitämän koulutettavuuden tulkintojen rajapinnalle, ja oma kyky opiskelijana ja oppijana tulee uudelleen arvioitavaksi koulun ylläpitämin arviointikriteerein. Koulujärjestelmä ylläpitää institutionaalista koulutettavuuden eetosta, joka jakaa opiskelijat kykyjensä mukaisiin kategorioihin "hyvät", "keskinkertaiset" ja "huonot" (Räty \& Snellman 1998). Koulujen ylläpitämään koulutettavuuden eetokseen sisältyvät myös sukupuolen (esim. miesten ja naisten kyvyt) ja sosiaalisen aseman (esim. teoreettiset ja käytännön kyvyt) mukaiset julkilausumattomat erottelut. Niin ikään ikäsidonnaiset odotukset tarjoavat normatiivisen mallin, jonka mukaan esimerkiksi lukio käydään nuorena eikä aikuisuudessa. Huolimatta painottamastaan kaikkia koskevasta koulutettavuudesta myös elinikäinen oppiminen näyttäytyy keskiluokkaisena individualistena normina, jota vasten yksilöä arvotetaan (vrt. Skeggs 2005).

Tarkastelen tutkimuksessani, miten koulutettavuuden suhteen rakentuvat sosiaaliset erot suhteessa ikään, sosiaaliluokkaan ja sukupuoleen jäsentävät aikuisopiskelijoiden koulutuselämänhistorioiden merkityksenantoa ja elämänhistoriallista työtä. Luen aikuisopiskelijoiden elämänhistorioita historialliseen ja sosiokulttuuriseen kontekstiin sijoittuvina ja subjektiiviseen elämänkulkuun kiinnittyvinä kertomuksina (ks. Alheit \& Dausien 2002, Ojala 2005). Ne ovat haastattelutilanteessa tehtyjä tulkintoja minästä, elämäntapahtumista ja oppimisen ja opiskelun merkityksistä elämänhistorian kokonaisuudessa.

\section{Esimerkkeinä Henrin ja Ainon tarinat}

Seuraavassa kuvaan 34-vuotiaan Henrin ja 40-vuotiaan Ainon tarinat esimerkkeinä suoritussuuntautuneen ja joustavan oppimisen mallin mukaisesta elämänhistoriallisesta jatkuvuustyöstä (Siivonen 2010). Sekä Henri että Aino kuvaavat itseään hy- vinä oppilaina; he oppivat jo varhain koulutuksen ja koulussa menestymisen merkityksen ja arvon. Molemmat kuitenkin kertovat aloittaneensa työuransa 16-vuotiaana keskeytettyään opintonsa; Henri heti peruskoulun jälkeen ja Aino muutaman kuukauden kestäneiden lukio-opintojen jälkeen. Haastatteluhetkellä kummallakin oli vakituinen ja turvallinen työ samoissa organisaatioissa, joissa he olivat aloittaneet työskentelynsä 16-vuotiaina. Sekä Henri että Aino kuvaavat itseään innokkaina oppijoina. He kertovat osallistumisestaan työnantajiensa kannustamina sekä formaaliin, non-formaaliin että informaaliin opiskeluun ja oppimiseen työssä ja myös työpaikan ulkopuolella. Tämä on myös mahdollistanut heille organisaatioiden sisällä tapahtuneen työtehtävistä toisiin siirtymisen ja uralla etenemisen.

Henrin ja Ainon tarinat kuitenkin myös eroavat toisistaan. Henrin esittämät perustelut koulun keskeyttämiselle kietoutuvat ikään ja omaan kypsymättömään asenteeseen, Ainolla taas sosiaaliluokkaan ja taloudellisten resurssien puutteeseen. Myös tulevaisuuden suunnitelmat aikuislukiosta valmistumisen jälkeen ovat erilaiset. Henrille vanha työ ei enää tarjonnut riittävästi haasteita ja hän suunnitteli jatko-opintoja ja uutta uraa, Aino taas halusi jatkaa turvallisessa työssään, josta hän sanoi pitävänsä. Tämä myös asettaa heidät erilaisiin positioihin suhteessa elinikäiseen oppimiseen ja sen sisältämiin vaateisiin.

\section{Henrin tarina}

Henri kertoo itsestään ison perheen esikoisena, joka oppi jo varhain koulutuksen ja "hyvän oppilaan" kategoriaan kuulumisen merkityksen ja arvon: "Kotona aina katsottiin et mä luen läksyni ja luen kokeisiin ja katsottiin koulutodistukset ja reissuvihkot läpi ja silleen eli mä tiesin, että se pitää hoitaa hyvin, asiallisesti loppuun niin hyvin ku pystyn." Hän kuitenkin keskeytti koulunkäynnin peruskoulun jälkeen, huolimatta kodin kannustuksesta keskiluokkaisten akateemisten arvojen mukaiseen koulutukseen. Henri kertoo, kuinka kesätyö kääntyi 16 vuotta kestäneeksi menestyksekkääksi uraksi: "Ihan täyden urakierron tehny siellä, ihan esimieskoulutustehtävistä ja työnopastustehtävistä ja ihan tonne normaaliin suoritustasoon ja sielläki katsottu noi eri suoritteet läpi että aika kattava kokemus." Hän kuvaa työuraansa "tavallisena" 80-luvun nousukauden tarinana. 
Henrin moraalisessa kehityskertomuksessa murrosikä muodostaa särön, joka tarjoaa "luonnollisen" ja siten hyväksyttävän selityksen olla valitsematta lukio-opiskelua normatiivisesti nuoruudessa: "[S] e oli se vaihe ihmisen elämässä että ni aikuisten järkipuheita ei enää kuunneltu niin tarkkaan." Murrosikä rakentuu Henrin kerronnassa tiettyä psykologista kehitysvaihetta vastaavana ikäkautena (Aapola 2002, Rantamaa 2001) ja asettuu vastakkain suhteessa kypsään ja rationaaliseen aikuisuuteen. Murrosikäisen nuoren nähdään kypsyvän korkeampaan kehitysvaiheeseen ja saavuttavan kypsän aikuisuuden, jolloin hän jättää taakseen ongelmalliseksi tulkitun murrosiän. Katri Komulainen $(1998,192)$ on sosiaalialan opiskelijoita koskevassa tutkimuksessaan nimennyt aikuistumiskertomuksiksi sellaiset muutoskertomukset, joissa muutosprosessi kerrotaan päähenkilön kasvuna ja kypsymisenä. Tällöin mennyt minä kuvataan alkeellisempana kuin nykyinen minä.

Noin kolmenkymmenen vuoden iässä Henri kertoo alkaneensa pohtia: "[M]ikä musta tulee isona." Hän kertoo leipääntyneensä pikkuvirkamiehen kellontarkkaan elämään. Ura ei edennyt toivotulla tavalla eikä työ enää tarjonnut hänelle riittävästi haasteita. Toisin kuin Aino hän kuvaa turvallista, vakituista työpaikkaa ja vakituista toimeentuloa oravanpyöränä, josta oli päästävä irti: "[H]aluan tehä vaan jotain muuta, (...) lähteä eläkkeelle jostain muusta hommasta." Myös toisin kuin tutkimuksen aikuisopiskelijat yleensä Henri näkee moraalisesti kypsän aikuisuuden parhaana elämänvaiheena osallistua muodolliseen koulutukseen.

Henri kuvaa aikuislukio-opintojen aloittamista "renessanssina" ja uutena alkuna: "[Se oli] varmasti mun elämäni yks parhaita siirtoja, mitä mä koskaan tein (...), että mä hakeuduin lukio-opintojen pariin." Henrin tarinaa voi tulkita keskiluokkaisena maskuliinisena sankaritarinana, jossa päähenkilö luopuu menestyksekkäästä urasta omasta tahdostaan. Se on myös uudesti syntymisen tarina, jossa päähenkilö tunnistaa itsessään sellaisia ominaisuuksia, joiden hän ei uskonut olevan olemassa. Henrin kehityskertomuksessa päähenkilö hylkää ajatuksen, että hän on "luonnostaan" huono matematiikassa ja kertoja osoittaa olevansa matemaattisesti lahjakas. Onnistuminen opinnoissa ja erityisesti matematiikassa on Henrin kerronnassa keskeisellä sijalla hänen suunnitellessaan jatko-opintoja ja uutta uraa.
Kuten Katri Komulaisen (1998, 185) tutkimuksessa syntymisen metaforaa käytetään kuvaamaan “minää", joka on aina ollut mutta kadonnut ja joka on löydettävissä koulutuksen avulla. Tämä tulee myös esiin Henrin kertoessa, että hän ei ole "mikään käytännön ihminen", vaan ylioppilastutkinto ja sen mahdollistama akateeminen ura "on ollu niinku se ykkönen aina". Muutos käsityksessä itsestä oppijana ja opiskelijana on edellytys sille, että päähenkilöstä voi kehittyä elinikäisen oppimisen ideaalin mukainen vastuullinen ja "oikean asenteen" omaava koulutettava subjekti, joka on myös työmarkkinoiden käytettävissä ja uudelleen työllistettävissä.

\section{Ainon tarina}

Lukio-opintojen keskeytyminen Ainon nuoruudessa kytkeytyy hänen lapsuudenkotinsa taloudellisiin resursseihin, joita hän kuvaa niukoiksi ja elämää rauhattomaksi ja turvattomaksi. Yksinhuoltajaäidillä ei ollut aikaa tai energiaa auttaa läksyjen teossa. Positioitumisen työväenluokkaan on nähty lannistavan työväenluokkaisia lapsia ja nuoria käymästä koulua ja hankkimasta koulutusta (ks. Käyhkö 2006, 2008; Skeggs 1997; Walkerdine ym. 2001; Willis 1977). Meritokratiaan perustuva yhtenäinen peruskoulu ei ole myöskään poistanut koulutettavuuden suhteen rakentuvia sosiaalisia eroja suomalaisesta koulujärjestelmästä (ks. esim. Hautamäki ym. 2000, Kuusinen 1992, Räty 2006, Räty ym. 2006). Aino kertoo kuitenkin halunneensa jatkaa lukio-opintojaan nuoruudessaan ja ilmaisee pettymyksensä, kun joutui ne keskeyttämään. Hänen kykynsä opiskelijana ja oppijana ei ollut esteenä hänen opiskelulleen, vaan tarve ansaita itse elantonsa: "Meiän perheessä suunnilleen kuolee nälkään (naurua) jos en mä mee töihin (...) oisin mä halunnu jäädä sinne."

Markku Vanttaja (2002, 121-122) on tutkimuksessaan koskien ylioppilaskirjoituksissa kaikkein menestyneimpiä opiskelijoita osoittanut, että ne opiskelijat, joita hän kutsuu "selviytyjiksi" kokivat koulun säännöllisen rytmin ja käytännöt turvallisiksi vastakohtana kodin ennalta arvaamattomille olosuhteille. Koulussa pärjääminen tarjosi turvaa näille opiskelijoille. Sukulaisten tai naapureiden luona nukuttujen öidenkin jälkeen Aino kertoo aina menneensä kouluun ja keskittyneensä opiskeluun.

Kuten Mari Käyhkön $(2008,262)$ tutkimuksen työväenluokkaisille tytöille, työllä on merkittävä 
asema Ainon elämässä. Kuitenkin toisin kuin Käyhkön tutkimuksessa, työ ei näyttäydy Ainolle ainoastaan keinona ansaita elantonsa, se on hänelle myös keino itsensä toteuttamiseen. Vakituinen työ on tarjonnut Ainolle mahdollisuuden läpi työuran jatkuneeseen itsensä kehittämiseen: "Mul on (...) kiva työ, se on hirveen tärkeetä, ihanat työkaverit, meil on hirveen hyvä henki täällä ja (...) ja sit tääl on semmonen että saa kehittää itteänsä, mä pääsen kursseille ja koulutuksee ulkopuolelleki. " Aino on aineistossa ainoa aktiivisesti työelämässä oleva aikuisopiskelija, jolla ei ollut aikomusta vaihtaa työpaikkaa ja pyrkiä urallaan eteenpäin. Olen tulkinnut että koulu sekä vakituinen ja turvallinen työ ovat tuoneet Ainon elämään tasapainoa, jota rauhaton lapsuuden koti ei tarjonnut (vrt. Vanttaja 2002 yllä).

Ainon tarina on työväenluokkaisen työssäkäyvän naisen tarina. Aino opiskelee jatkuvasti ja elämänlaajuisesti kehittääkseen itseään: formaaleissa tutkintoihin tähtäävissä instituutioissa kuten aikuislukiossa, ei-formaaleilla kursseilla kuten kuurojen koulussa tai työpaikan järjestämillä kursseilla ja informaalisti arkielämässä. Oppiminen itsessään rakentuu hänen kerronnassaan tyydyttävämmän elämän mahdollistajana, mahdollisuutena itsensä kehittämiseen: "Ihminen vois kehittää itseään koko elämänsä." Hän kuitenkin kehittää itseään ilman ulkoisia merkkejä kuten jatko-opintoja ja uutta uraa, jotka länsimaissa tulkitaan osoitukseksi yksilön kyvykkyydestä (ks. Komulainen 1998, 11). Ylioppilastutkintoon tähtäävä ja uusia jatko-opintomahdollisuuksia avaava aikuislukiokin saa merkityksensä harrastuksena, vastakohtana vakavasti otettavalle yhteiskunnallisesti merkitykselliselle toiminnalle, joka johtaa jatko-opintoihin, uuteen työhön tai sosiaaliseen nousuun. Tässä mielessä hän edustaa paikalleen jäämistä muutoksen sijaan. Elinikäisen oppimisen keskiluokkaisen normin mukaisesti hänen työväenluokkainen valintansa määrittyy vääräksi ja vähemmän arvokkaaksi. Tästä syystä hänelle tarjoutuu asema elinikäisen oppimisen reunamilla, ei sen keskiössä.

Sekä Henri että Aino kehittävät itseään "uuteen aikuisuuteen" liittyvän vaateen mukaisesti: ihminen ei ole koskaan valmis, vaan aina epätäydellinen ja uudistumisen tarpeessa (Koski \& Moore 2001). Kuitenkin siinä missä Henri suunnittelee jatko-opintoja joko ammattikorkeakoulussa tai yliopistossa ja uutta uraa, Aino opiskelee harrastuksena, sivistääkseen itseään ja saavuttaakseen tyy- dyttävämmän elämän. Hän ei suunnittele uuteen uraan tähtääviä jatko-opintoja. Henrin tarina on esimerkki niin sanotusta suoritussuuntautuneen mallin mukaisesta aikuisopiskelijasta, jolle oman pätevyyden osoittaminen muodollisesta koulutuksesta saaduin tutkinnoin rakentuu tärkeämmäksi kuin esimerkiksi työpaikan tarjoama koulutus. Aino puolestaan on aina opiskellut joustavasti erilaisissa oppimisympäristöissä. Hänelle nonformaali ja informaali oppiminen ja opiskelu ovat yhtälailla tärkeitä kuin instituutioissa tapahtuva tutkintoihin tähtäävä opiskelu. Oma kehittyminen rakentuu tärkeämmäksi kuin koulutuksen ulkoiset tunnusmerkit, arvosanat ja tutkinnot.

\section{Suoritussuuntautunut ja joustava oppiminen}

Seuraavassa kuvatut suoritussuuntautuneen ja joustavan oppimisen mallit kuvaavat tiivistetysti tutkimukseni tulokset. Tutkimukseen osallistuneesta 20 aikuisopiskelijasta kuusi rakensi elämänhistoriallista jatkuvuutta suhteessa omaan kykyynsä opiskella ja oppia joustavan mallin mukaisesti ja valtaosa suoritussuuntautuneesti. Joustavan mallin mukaisesti opiskelevista kaikki olivat naisia ja heistä Aino oli ainoa aktiivisesti työelämässä mukana oleva, kun taas suoritussuuntautuneista opiskelijoista kaikki olivat aktiivisesti mukana työelämässä. Vastoin elinikäisen oppimisen periaatetta tasa-arvoisista mahdollisuuksista oppia ja kouluttautua tutkimuksen perusteella näyttäisi siltä, että hegemoninen maskuliinisuus avaa tietä oppimisyhteiskunnan ideaaliin ja elinikäisen oppimisen ideaalin mukainen koulutettavan ja työllistettävissä olevan subjektin konstruktio on helpommin miehen kuin naisen saavutettavissa (ks. Siivonen 2010, 190). Näin siitä huolimatta, että enemmistö tutkimukseen osallistuneista ja aikuiskoulutukseen osallistuvista yleensä on naisia.

Henrin esimerkkitarinan mukaisesti suoritussuuntautuneessa oppimisen mallissa jatkuvuus rakentuu läheisessä suhteessa elinikäisen oppimisen periaatteisiin. Joustavuus, sopeutuvuus, työllistettävyys ja valmius selviytyä jatkuvasti muuttuvissa olosuhteissa nähdään tärkeinä. Vastoin elämänlaajuista oppimista oman pätevyyden dokumentointi formaalein tutkinnoin on kuitenkin tärkeämpää kuin nonformaalit kurssit tai informaali oppiminen arkielämässä. Tutkinnot ja arvosanat ovat välttämättömiä kilpailtaessa jatko-opinnoissa ja työurilla sekä tavoiteltaessa korkeampaa so- 
siaalista asemaa. Ulkoiset kehityksen merkit rakentuvat vähintään yhtä tärkeiksi kuin itse oppiminen. Tämä koulutettava ja työllistettävissä oleva subjekti on omaksunut "uuden aikuisuuden" vaateet ja on jatkuvassa joksikin tulemisen tilassa, ei koskaan valmis vaan aina epätäydellinen (ks. Koski \& Moore 2001; Vilkko 1997). Hänelle lankeaa jo moraalinenkin velvollisuus kantaa vastuunsa ja tulla elinikäiseksi oppijaksi. Oman sisäisen potentiaalin kehittämiseen sisältyy moraalista säätelyä, joka Leena Kosken (2004) mukaan kiinnittyy koulutuspoliittiseen ideologiaan yksiön vastuusta osallistua kilpailuun sosiaalisista asemista jatkuvan työttömyyden ja kasvavan kilpailun värittämässä tulevaisuudessa.

Toisessa Ainon esimerkkitarinan mukaisessa joustavan oppimisen mallissa teoreettisen ja akateemisen oppimisen arvo kyseenalaistuu ja oma oppiminen ja kehittyminen nähdään tärkeämpänä kuin koulutuksen ulkoiset tunnusmerkit, arvosanat ja tutkinnot. Opiskelu ja oppiminen rakentuvat harrastuksena, sijaistekemisenä tai itsensä kehittämisenä ja keinona tyydyttävämpään elämään vastakohtana yhteiskunnallisesti merkitykselliselle toiminnalle: jatko-opinnoille ja työuralla etenemiselle. Tämä ei kuitenkaan tarkoita, ettei tällä koulutettavalla subjektilla olisi elinikäisen oppijan ominaisuuksia. Hänestä piirtyy kuva uteliaana ja kiinnostuneena, aktiivisena, itsenäisenä ja itseohjautuvana ja pääasiassa hyvänä oppilaana. Tämä oppija etsii oppimismahdollisuuksia yhtälailla sekä elinikäisesti että elämänlaajuisesti erilaisissa oppimisympäristöissä. Tämä ei kuitenkaan takaa hänelle itsestään selvästi pääsyä oppimisyhteiskunnan ideaaliin. Koulutettavana mutta ei (uudelleen) työllistettävissä olevana subjektina hän sijoittuu elinikäisen oppimisen reunamille ja takapihalle liittyen sosiaaliluokkaansa, sukupuoleensa ja ikäänsä kietoutuviin positioihin.

Huolimatta elinikäisen oppimisen painottamasta kaikille tasa-arvoisista mahdollisuuksista oppia ja opiskella kaikilla ei ole kuitenkaan mahdollista rakentaa itsestään elinikäisen oppimisen ideaalin mukaista koulutettavaa subjektia. Suoritussuuntautuneen ja joustavan oppimisen mallit kuvaavat, ketä kannattaa kouluttaa ja miten (Siivonen 2010). Valmius (uudelleen) työllistyä on tutkimukseni mukaan olennainen osa elinikäisen oppimisen ideaalia. Koulutettavan ja työllistettävissä olevan elinikäisen oppimisen subjektin tulee osallistua formaaliin koulutukseen saavuttaakseen tutkintoja työelämää varten, kun taas koulutettava mutta ei työllistettävissä oleva subjekti voi oppia elämänlevyisesti omaksi ilokseen. Ne tutkimukseeni osallistuneet aikuisopiskelijat, jotka ovat koulutettavia mutta eivät työllistettävissä olevia arvostavat eniten elämänlevyistä oppimista eri oppimisympäristöissä. Tämä on ristiriidassa suhteessa elinikäisen oppimisen tavoitteeseen taata joustavan, sopeutuvan ja työllistettävän työvoiman riittävyys yhtälailla elinikäistä kuin elämänlevyistä oppimista hyödyntäen. Nonformaali ja informaali oppiminen näyttäytyy merkityksellisenä toimintana vasta silloin kun se on formaalein dokumentein ja todistuksin osoitettu (Tushling \& Engemann, 2006, ks. myös Olssen, 2006).

\section{0-Iuvun aikuislukion haasteita ja mahdollisuuksia}

Aikuislukion tehtävä on perinteisesti ollut sosiaalinen. Se on tarjonnut mahdollisuuden opiskeluun ja itsensä sivistämiseen myös niille, joilla ei tätä mahdollisuutta ole taloudellisista tai muista syistä johtuen muutoin ollut. Aikuislukiot ovat koko pitkän historiansa ajan olleet edelläkävijöitä yksilöllisten ja joustavien opiskelumahdollisuuksien kehittämisessä aikuisille. Aikuislukioissa kehitettyjä ja hyväksi havaittuja käytäntöjä, kuten luokattomuus ja kurssimuotoinen opiskelu on otettu käyttöön laajemminkin. Myös elinikäisen oppimisen toteuttajina aikuislukiot ovat toimineet edelläkävijöinä ja omaksuneet oppimisen ja opiskelun tavoitteet yhä vahvemmin työelämän lähtökohdista käsin (ks. esim. OPH 2004, OPM 2006). Aikuislukioihin kuten aikuiskoulutukseen yleensäkin hakeudutaan tavoitteena paremmat jatko-opintomahdollisuudet, työuralla eteneminen ja sosiaalinen nousu (Siivonen 2010). Oppiminen ja opiskelu itsenä kehittämisenä ja sivistämisenä ovat jääneet taloudellisista motiiveista nousevien tavoitteiden varjoon.

Aikuislukioissa ollaan syystäkin huolissaan tulevaisuudesta. Yleisen koulutustason huomattava nousu vaikuttaa olennaisesti aikuisten perusopetuksen ja lukiokoulutuksen tarpeeseen nyt ja tulevaisuudessa (OPM 2006, 21). Tämä koskee erityisesti lukiotutkinnon suorittamisen tarvetta (mt., 33). Myös ikäluokkien pienentyminen vähentää tutkintoon tähtäävien opiskelijoiden määriä (mt., 23-25). Sen sijaan yksittäisissä aineissa kursseja suorittavien määrät ovat lisääntyneet, minkä nähdään heijastavan työelämän muutoksia ja aikuisten lisääntyvää tarvetta päivittää osaamistaan 
(mt., 50). Tutkintojen suorittamisen määrään perustuvan rahoitusjärjestelmän seurauksena aineopiskelua ei kuitenkaan edelleenkään huomioida valtionosuuden määräytymisessä, vaikka aineopiskelun järjestämisestä on säädetty asetuksella (mt, 50-51). Tilanne on omiaan asettamaan yhteistyötä tekevät ja keskenään verkostoituneet aikuislukiot keskinäiseen kilpailutilanteeseen.

Muutoksista huolimatta tai niistä johtuen oppimisen tarve säilyy eittämättä vahvana myös tulevaisuudessa: oppimista tapahtuu niin formaaleissa instituutioissa kuin epävirallisemmin työssä, kansan- ja työväenopistoissa sekä arkielämässä. Aikuislukioiden ja aikuiskoulutuksen näkökulmasta tilanne luo myös uusia mahdollisuuksia. Sen sijaan, että aikuislukiöiden toiminta perustuu lähes yksinomaan työelämän muutoksista kumpuavaan elinikäiseen oppimiseen, aikuislukioilla olisi hyvät edellytykset jo historiansakin valossa toimia koulutuksen kulutusmallin vastavoimana ja asettua näyttämään tietä demokraattisemman ja solidaarisemman lukiokoulutuksen puolesta. $\mathrm{Ku}$ ten Mark Olssen $(2006,225)$ on esittänyt "me kaikki olemme, tai meidän tulisi olla osa tulevaisuuden oppimisyhteiskuntaa." Hänen mukaansa "[t]ärkein kysymys kuuluu, mitä tarkoitusta varten oppimismahdollisuuksia tulisi olla saatavilla, mitä tarkoitusperiä oppimisen tulisi palvella?" Hän ehdottaa ratkaisuksi oppimisen mallia, joka perustuu "sosiaaliseen ja poliittiseen osallistumiseen globaalissa yhteisössä" (mt., 226). Oppimisen tulisi ennen kaikkea palvella kansalaisten demokraattista osallistumista tavoitteena kehittää entistä tasa-arvoisempaa yhteiskuntaa. (Olssen 2006.)

Aikuislukio instituutiona, joka rohkaisee niitä, joilla ei ole ollut mahdollisuutta kouluttautua nuoruudessaan ja/tai heti peruskoulun jälkeen on osaltaan varteenotettava tulevaisuuden malli tasa-arvoisten opiskelumahdollisuuksien edistämisessä. Aikuislukiot tarjoavat joustavia opiskelumahdollisuuksia eri-ikäisille naisille ja miehille, erilaisista sosiaalisista taustoista tuleville sekä eri tavoin erilaisille oppijoille. Tämä on se sosiaalinen perusta, jonka pohjalta olisi hedelmällistä kehittää edelleen suomalaisen lukiokoulutuksen suuntaa demokraattisista ja solidaarisista lähtökohdista käsin.

\section{Viite}

1. Nimet ovat muutettuja.

\section{Lähteet}

Aapola, S. (2002). Exploring dimensions of age in young people's lives: A discourse analytical approach. Time \& Society, 11(2/3), 295-314.

Alheit, P. \& Dausien, B. (2002). Lifelong learning and 'biographicity': Two theoretical views on current educational changes. In Bron, A. \& Schemmann, M. (Eds.), Social science theories in adult education research. Münster: LIT Verlag, 211-241.

Billig, M., Condor, S., Edwards, D., Gane, M., Middleton, D. \& Radley, A. (1988). Ideological dilemmas: A social psychology of everyday thinking. London: SAGE.

Brine, J. (2006). Lifelong learning and the knowledge economy: Those that know and those that do not - the discourse of the European Union. British Educational Research Journal, 32(5), 649-665.

Edwards, R. (1997). Changing places? Flexibility, lifelong learning and a learning society. London: Routledge.

Edwards, R. (2002). Mobilizing lifelong learning: governmentality in educational practices. Journal of Educational Policy, 17(3), 353365.

Fejes, A. (2005). New wine in old skins: Changing patterns in the governing of the adult learner in Sweden. International Journal of Lifelong Education, 24(1), 71-86.

Fejes, A. (2006). The planetspeak discourse of lifelong learning in Sweden: What is an educable adult? Journal of Educational Policy, 21(6), 697-716.

Filander, K. (2007). Deconstructing dominant discourses on vocational education. In Rinne, R., Heikkinen, A. \& Salo, P. (Eds.), Adult education - liberty, fraternity, equality? Nordic views on lifelong learning. Research in Educational Sciences 28. Turku: Finnish Educational Research Association, 261-274.

Hautamäki, J., Arinen, P., Hautamäki, A., Kupiainen, S., Lindblom, B., Niemivirta, M. \& Scheinin, P. (2000). Oppimaan oppiminen yläasteella. Helsinki: Opetushallitus.

IKLO Iltakoulujen liitto. (2007). http:// www.aikuislukiot.fi/

IKLO Iltakoulujen liitto. (n.d.). http://www.iklo.fi/ 
Esittely.html (Luettu 14.4.2010.)

Jauhiainen, A. \& Alho-Malmelin, M. (2004). Education as a religion in the learning society. International Journal of Lifelong Education, 23( 5), 459-474.

Jokinen, J. (2002). Aikuisopettajan identiteetti. Acta Universitatis Tamperensis 898. Tampere: Tampereen yliopistopaino.

Jääskeläinen, L. (27.7.2007). Aikuisten yleissivistävän opetuksen kehittämisehdotukset yksissä kansissa. Opinsauna [Juhlanumero], 6.

Kallioniemi, A. (2000). Aikuislukion opiskelijoiden uskomukset uskonnon- ja historianopetuksesta. Helsingin yliopiston opettajankoulutuslaitoksen tutkimuksia 210. Helsingin yliopisto.

Komulainen, K. (1998). Kotihiiriä ja ihmisiä: Retorinen minä naisten koulutusta koskevissa elämänkertomuksissa. Joensuun yliopiston yhteiskuntatieteellisiä julkaisuja 35. Joensuun yliopistopaino.

Koski, L. (2004). Yksilöllisyyden moraalisuus koulutuspolitiikassa. Kasvatus, 35(1), 79-90.

Koski, L. \& Moore, E. (2001). Näkökulmia aikuisuuteen ja aikuiskasvatukseen. Aikuiskasvatus, 21(1), 4-13.

Kumpulainen, T. (toim.) (2009). Aikuiskoulutuksen vuosikirja: Tilastotietoja aikuisten opiskelusta 2007. Opetusministeriön julkaisuja 2009:42. Osoitteessa http://www.oph.fi/ download/114801_opm42.pdf(Luettu 19.6.2010.)

Kuusinen, J. (1992). Hyvät, huonot ja keskinkertaiset: virkaanastujaisesitelmä Jyväskylän yliopistossa 6.11.1991. Kasvatus, 23(1), 4756.

Käyhkö, M. (2006). Siivoojaksi oppimassa: Etnografinen tutkimus työläistytöistä puhdistuspalvelualan koulutuksessa. Joensuun yliopistopaino.

Käyhkö, M. (2008). Kädenjälki näkyviin — koulunpenkkiä väistelevät nuoret työläisnaiset. Teoksessa Tolonen T. (toim.) Yhteiskunta ja sukupuoli. Nuorisotutkimusverkosto/Nuorisotutkimusseura julkaisuja 83. Tampere: Vastapaino, 255-273.

Linde, C. (1993). Life stories: The creation of coherence. New York: Oxford University Press.

Nyyssölä, K. \& Hämäläinen, K. (2002). Elinikäi- nen oppiminen Suomessa ja muualla. Aikuiskasvatus, 22(1), 42-47.

Ojala, H. (2005). Ikääntyneenä naisena opiskelemassa - hyödyn ja sivistyksen rajankäyntiä. Teoksessa Mietola, R., Lahelma, E., Lappalainen, S. \& Palmu T. (toim.), Kohtaamisia kasvatuksen ja koulutuksen kentillä: erontekoja ja yhdessä tekemistä. Turku: Suomen Kasvatustieteellinen Seura, 51-66.

Olssen, M. (2006). Understanding the mechanisms of neoliberal control: Lifelong learning, flexibility and knowledge capitalism. International Journal of Lifelong Education, 25(3), 213-230.

OPH. (2004). Aikuisten perusopetuksen ja lukiokoulutuksen opetussuunnitelman perusteet 2004. Opetushallitus (4.11.2004). Osoitteessa http://www.oph.fi/aikuisops/ aikuisperusteet.pdf

OPM. (2006). Aikuisten perusopetuksen ja lukiokoulutuksen kehittämisohjelmaehdotus vuosiksi 2007-2012. Opetusministeriön työryhmämuistioita ja selvityksiä 2006:33. Osoitteessa http://www.minedu.fi /OPM/Julkaisut/ 2006/ (Luettu 20.2.2007.)

Popkewitz, T. S. (1991). A political sociology of educational reform: Power/knowledge in teaching, teacher education, and research. New York: Teachers College Press.

Rantamaa, P. (2001). Ikä ja sen merkitykset. Teoksessa Sankari, A. \& Jyrkämä, J. (toim.), Lapsuudesta vanhuuteen: Iän sosiologiaa. Tampere: Vastapaino, 49-93.

Räty, H. (2006). What comes after compulsory education? A follow-up study on parental expectations of their child's future education. Educational Studies, 32 (1), 1-16.

Räty, H., Kasanen, K. \& Kärkkäinen, R. (2006). School subjects as social categorisations. Social Psychology of Education 9, 5-25.

Räty, H. \& Snellman, L. (1998). Social representations of educability. Social Psychology of Education 1, 359-373.

Salomaa, M. (2002). Yrjö ja Hilma Jahnsson ensimmäisen iltaoppikoulun perustajina ja kehittäjinä. Teoksessa Hallikainen, P., Larjontie, T., Mäkelä, A., Paakkunainen, R., Salomaa, M. \& Vepsä, H. (toim.) Iltaoppikoulusta aikuislukioksi: 75 vuotta kulttuurityötä 1927-2002. Jyväskylä: Gummerus, 7-22. 
Siivonen, P. (2010). From a "student" to a lifelong "consumer" of education? Constructions of educability in adult students' narrative life histories. Research in Educational Sciences 47. Jyväskylä: Finnish Educational Research Association.

Skeggs, B. (1997). Formations of class and gender: Becoming respectable. London: SAGE.

Skeggs, B. (2005). The making of class and gender through visualizing moral subject formation. Sociology, 39(5), 965-982.

Tilastokeskus/Perusasteen jälkeisen tutkintotavoitteisen koulutuksen opiskelijat ja tutkinnot koulutusmaakunnan, koulutuslajin ja opintoalan (opetushallinnon luokitus) mukaan. (2008). (Päivitetty 26.1.2010). Osoitteessa http://pxweb2.stat.fi/Dialog/Saveshow.asp (Luettu 19.6.2010).

Tilastokeskus/Ylioppilastutkinnot. (2003). Julkaisematon lukioaineisto, saatu 15.5.2004 Suomen tilastokeskukselta.

Tuschling, A. \& Engemann, C. (2006). From education to lifelong learning: The emerging regime of learning in the European Union. Edu- cational Philosophy and Theory, 38 (4), 451-469.

Vanttaja, M. (2002). Koulumenestyjät: Tutkimus laudaturylioppilaiden koulutus- ja työurista. Turku: Suomen Kasvatustieteellinen Seura.

Vihervaara, E. (20.2.2007). Yleissivistystä on mahdollista päivittää aikuislukioissa. $\mathrm{HS} \mathrm{Hel-}$ singin Sanomat 20.2.2007.

Vilkko, A. (1997). Omaelämänkerta kohtaamispaikkana-Naisen elämän kerronta ja luenta. Suomalaisen kirjallisuusseuran toimituksia 663. Tampere: Tammer-Paino.

Walkerdine, V., Lucey, H. \& Melody, J. (2001). Growing up girl: Psychosocial explorations of gender and class. Houndsmills: Palgrave.

Willis, P. (1977). Learning to labour: How working class kids get working class jobs. Westmead, England: Saxon House.

Zetterberg, S. (1982). Yrjö ja Hilma Jahnsson. Helsinki: Yrjö Jahnssonin säätiö.

Artikkeli saapui toimitukseen 23.4.2010.

Se hyväksyttiin julkaistavaksi toimituskunnan kokouksessa 16.8.2010.

\section{Asuuko henki lammessa?}

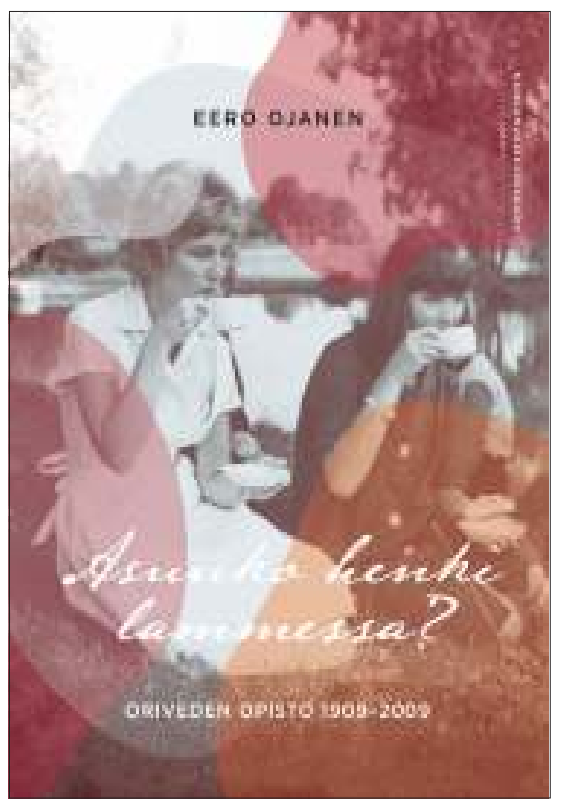

Eero Ojanen (2010). Asuuko henki lammessa?

Oriveden Opisto 1909-2009. Kansanvalistusseura, 301 sivua.

Sadassa vuodessa Oriveden Opisto on monella tapaa muuttunut mutta luova tekemisen henki on aina pysynyt. Maaseudun nuorten aikuisten yleissivistävästä opinahjosta opisto on kehittynyt vapaan sivistystyön ja taideopetuksen suunnannäyttäjäksi. Opisto tunnetaan maineikkaasta kirjoittajakoulutuksestaan, musiikkilinjastaan ja Klemetti-Opistostaan, kuvataidekoulutuksestaan ja nyt myös suositusta kirjoittajalukiostaan. Raikkaasti kuvitettu teos on myös ilo silmille! $\mathrm{OVH} 30$ euroa + toimituskulut

Verkkotilaukset: www.kansanvalistusseura.fi 